\title{
Protooncogene bcl-2 Gene Transfer Abrogates Fas/APO-1 Antibody-mediated Apoptosis of Human Malignant Glioma Cells and Confers Resistance to Chemotherapeutic Drugs and Therapeutic Irradiation
}

\author{
Michael Weller, * Ursula Malipiero, * Adriano Aguzzi, ${ }^{\star}$ John C. Reed, ${ }^{\mathfrak{5}}$ and Adriano Fontana* \\ * Section of Clinical Immunology, Department of Internal Medicine, and ${ }^{\ddagger}$ Department of Neuropathology, University Hospital Zürich, \\ Zürich, Switzerland; and ${ }^{8}$ La Jolla Cancer Research Foundation, Cancer Research Institute, La Jolla, California
}

\begin{abstract}
The majority of human malignant glioma cells express Fas/ APO-1 and are susceptible to Fas/APO-1 antibody-mediated apoptosis in vitro. The sensitivity of Fas/APO-1-positive glioma cell lines to Fas/APO-1 antibody-mediated killing correlates inversely with the constitutive expression of the antiapoptotic protooncogene $b c l-2$. Here we report that BCL-2 protein expression of human glial tumors in vivo correlates with malignant transformation in that BCL-2 immunoreactive glioma cells were more abundant in WHO grade III/IV gliomas than in grade I/II gliomas. Fas/APO-1 antibodysensitive human glioma cell lines stably transfected with a murine bcl-2 cDNA acquired resistance to Fas/APO-1 antibody-mediated apoptosis. Forced expression of bcl-2 also attenuated TNF $\alpha$-mediated cytotoxicity of glioma cell lines in the presence of actinomycin $D$ and cycloheximide and conferred partial protection from irradiation and the cancer chemotherapy drugs, cisplatin and BCNU. Preexposure of the glioma cell lines to the cytokines, IFN $\gamma$ and TNF $\alpha$, which sensitize for Fas/APO-1-dependent killing, partially overcame $b c l-2-$ mediated rescue from apoptosis, suggesting that multimodality immunotherapy involving cytokines and Fas/ APO-1 targeting might eventually provide a promising approach to the treatment of human malignant gliomas. (J. Clin. Invest. 1995. 95:2633-2643.) Key words: glioblastoma • brain tumor • programmed cell death • CD95 • immunotherapy
\end{abstract}

\section{Introduction}

Fas/APO-1 is a member of the TNF receptor/nerve growth factor receptor superfamily which signals apoptosis in susceptible target cells when bound by Fas/APO-1 ligand or agonistic antibodies

Address correspondence to Adriano Fontana, M.D., Section of Clinical Immunology, Department of Internal Medicine, University Hospital Zürich, Häldeliweg 4, CH-8044 Zürich, Switzerland. Phone: 1257 3813; FAX: 1257 2872. M. Weller's present address is Department of Neurology, University of Tübingen, School of Medicine, Hoppe-Seyler-Strasse 3, 72076 Tübingen, Germany.

Received for publication 5 December 1994 and in revised form 17 February 1995.

1. Abbreviations used in this paper: $\mathrm{ab}$, antibodies; $\mathrm{ActD}$, actinomycin D; BCNU, 1,3-bis (2-chloroethyl)-1-nitrosourea; CHX, cycloheximide.

J. Clin. Invest.

(C) The American Society for Clinical Investigation, Inc. $0021-9738 / 95 / 06 / 2633 / 11 \quad \$ 2.00$

Volume 95, June 1995, 2633-2643 $(\mathrm{ab})^{1}(1-5)$. We have previously shown that human malignant glioma cells express Fas/APO-1 in vitro and in vivo and are susceptible to Fas/APO-1 ab-mediated apoptosis in vitro (6). Independently, the screening of various tumor cell lines for Fas/ APO-1 expression and susceptibility to Fas/APO-1 ab-mediated apoptosis showed that all three glioma cell lines included expressed Fas/APO-1 and were killed by Fas/APO-1 ab $(7,8)$. Human malignant gliomas are largely resistent to current strategies of surgery, chemotherapy, radiotherapy and immunotherapy. Activation of the Fas/APO-1 pathway may be a novel promising approach to the management of malignant glioma (6). The antiapoptotic protooncogene, $b c l-2$, was first identified in follicular lymphomas which express high levels of BCL-2 protein as a consequence of a translocation of the $b c l-2$ gene from chromosome $18 \mathrm{q} 21$ to $14 \mathrm{q} 32(9)$. The translocation results in increased transcription and translation of the $b c l-2$ gene because of the proximity to strong enhancer elements in the adjacent immunoglobulin heavy chain gene locus. Forced expression of bcl-2 inhibits apoptosis triggered by various death stimuli including growth factor deprivation (10), irradiation (11-15), and cancer chemotherapy drugs (16-21). By virtue of these properties, enhanced $b c l-2$ expression in the absence of chromosomal translocations may play a role in the malignant progression of prostate cancer (22) and neuroblastoma (23). In contrast to astrocytes of the adult brain in vivo $(24,25), b c l-2$ is expressed in some human malignant glioma cell lines $(6,26)$. Further, we have observed a negative correlation between the sensitivity to Fas/ APO-1-dependent apoptosis of Fas/APO-1 - positive human glioma cells and their endogenous $b c l-2$ expression (6). Here we report that human malignant gliomas express BCL-2 protein in vivo and that stable transfection of the murine $b c l-2$ gene into human malignant glioma cells confers resistance not only to Fas/APO-1 ab-mediated glioma cell apoptosis but also to the cytotoxic effects of TNF $\alpha$, irradiation and cancer chemotherapy drugs. The antiapoptotic effects of $b c l-2$ can be partially overcome by preexposure of the glioma cells to IFN $\gamma$ and TNF $\alpha$.

\section{Methods}

Materials. The human malignant glioma cell lines LN-18 and LN-229 were kindly provided by Dr. N. de Tribolet (Lausanne, Switzerland). T98G human glioma cells and MCF-7 mammary carcinoma cells were obtained from ATCC (Rockville, MD). M07e human myeloid leukemia cells were kindly provided by Dr. B. Fagg (Sandoz, Basel, Switzerland). L-M murine fibroblasts were obtained from Genentech (San Francisco, CA). The reagents for in situ DNA end labeling, immunochemistry and Western blot analysis have previously been detailed (6, 27). G418 was purchased from Gibco BRL (Basel, Switzerland). Cisplatin was obtained from Sigma Chemical Co. (St. Louis, MO), 3-bis(2-chloroethyl)-1-nitrosourea (BCNU) from Bristol (Syracuse, NY). Cytotoxic IgM Fas ab and FITC-labeled IgG Fas ab were purchased from Kamiya 

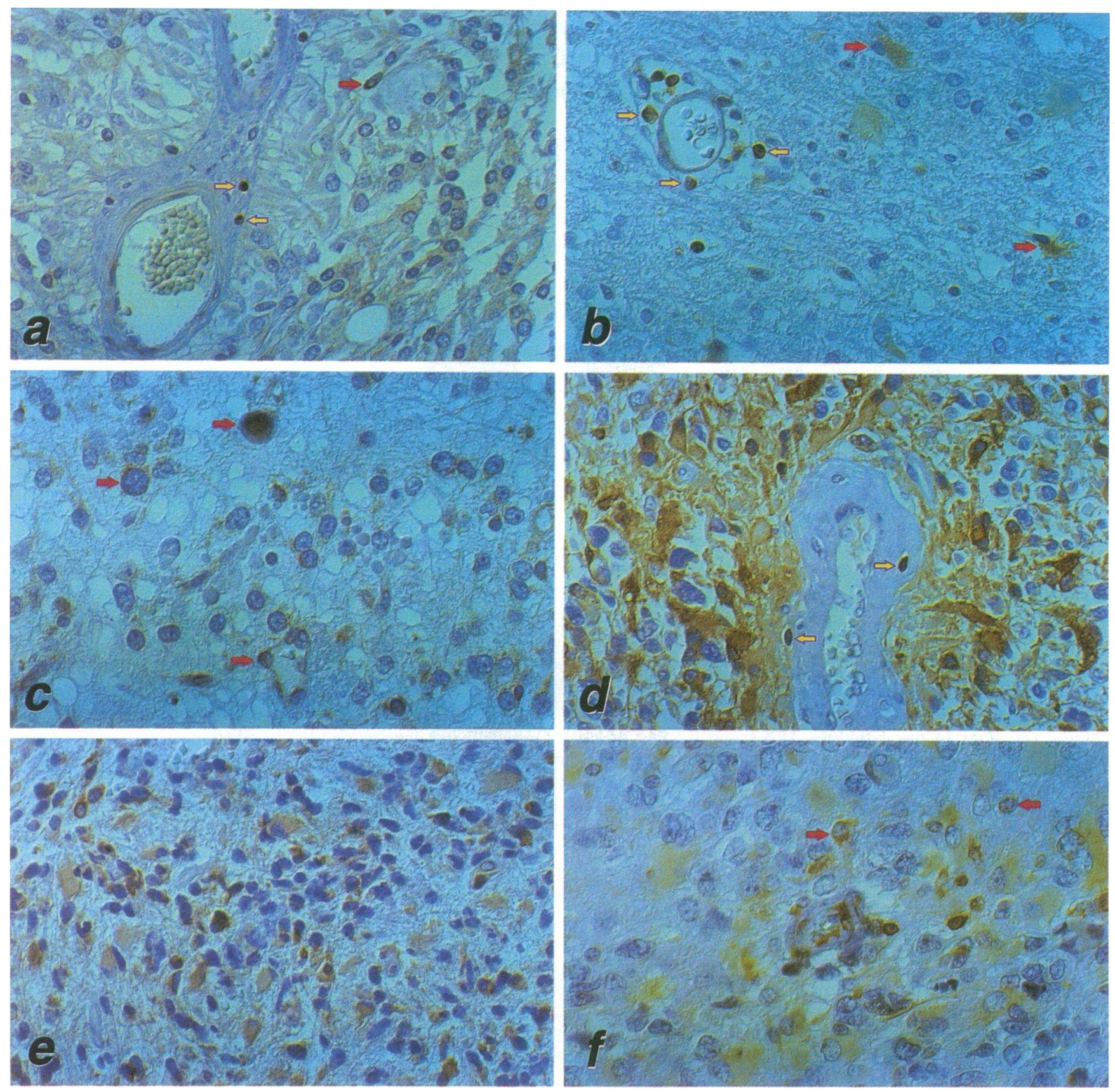

Figure 1. Human gliomas express BCL-2 protein in vivo. Sections obtained from brain tumors of different WHO malignancy grades were stained for BCL-2 protein as described in Methods. The brown colour of the peroxidase substrate, diaminobenzidene, corresponds to the specific staining for BCL-2. The slides were counterstained with haematoxylin $(\times 190)$. (a) pilocytic astrocytoma (WHO grade I, case no. 89-9387); $(b)$ fibrillary astrocytoma (WHO grade II, case no. 94-363); (c) anaplastic oligoastrocytoma (WHO grade III, case no. 94-791); (d) anaplastic astrocytoma with prominent gemistocytic component (WHO grade III, case no. 93-1301); $(e$ and $f$ ) glioblastomas $(e)$ primary small cell glioblastoma, case no. 93-196; $(f)$ secondary glioblastoma, case no. 94-461). Several positive tumor cells are marked with red arrows. Perivascular tumor-infiltrating lymphocytes (yellow arrows) express BCL-2 and serve as an internal control. Endothelial cells within the tumor tissue are negative.

(Thousand Oaks, CA). Anti-human BCL-2 ab was obtained from Dakopatts (Glostrup, Denmark).

Cell culture and detection of apoptosis. The glioma cell lines were maintained in DME containing $10 \%$ FCS, $1 \mathrm{mM}$ glutamine and $10 \mu \mathrm{g} /$ ml gentamycin (6). M07e cells were cultured in RPMI 1640 containing $5 \%$ FCS, $1 \mathrm{mM}$ glutamine, $100 \mathrm{U} / \mathrm{ml}$ penicillin, $100 \mu \mathrm{g} / \mathrm{ml}$ streptomycin, $100 \mu \mathrm{M}$ 2-ME, and $10 \mathrm{ng} / \mathrm{ml}$ human recombinant IL-3 (28). L-M murine fibroblasts were cultured as previously described (29). Irradiation was performed using a ${ }^{60}$ cobalt source. Viability and proliferation were assessed by crystal violet staining and by $\left[{ }^{3} \mathrm{H}\right]$ thymidine incorporation. The methods for the detection of apoptosis including DNA agarose gel electrophoresis, quantitative fluorometric DNA fragmentation assay and in situ DNA end labeling have previously been reported $(6,27)$.

Flow cytometry. For flow cytometric cell cycle analysis, M07e cells were fixed for $10 \mathrm{~min}$ on ice in $70 \%$ ethanol in PBS, stained with propidium iodide $(50 \mu \mathrm{g} / \mathrm{ml})$ in PBS containing $100 \mu \mathrm{g} / \mathrm{ml}$ RNase A ( $30 \mathrm{~min}, 37^{\circ} \mathrm{C}$ ), and washed twice in PBS containing $1 \%$ formaldehyde. 
Table I. Human Gliomas Express BCL-2 Protein In Vivo

\begin{tabular}{llcc}
\hline \multicolumn{1}{c}{ No. } & \multicolumn{1}{c}{ Diagnosis } & $\begin{array}{c}\text { WHO } \\
\text { grade }\end{array}$ & BCL-2 \\
\hline $89-9387$ & Pilocytic astrocytoma & I & $(+)$ \\
$89-9518$ & Pilocytic astrocytoma & I & - \\
$89-24198$ & Pilocytic astrocytoma & I & $(+)$ \\
$89-36082$ & Pilocytic astrocytoma & I & + \\
$93-270$ & Fibrillary astrocytoma & II & ++ \\
$93-367$ & Fibrillary astrocytoma & II & + \\
$93-420$ & Fibrillary astrocytoma & II & $(+)$ \\
$94-363$ & Fibrillary astrocytoma & II & + \\
$93-1292$ & Nongemistocytic anaplastic astrocytoma & III & +++ \\
$93-1301$ & Gemistocytic anaplastic astrocytoma & III & ++++ \\
$93-1335$ & Nongemistocytic anaplastic astrocytoma & III & + \\
$94-791$ & Anaplastic oligoastrocytoma & III & ++ \\
$93-196$ & Glioblastoma & IV & +++ \\
$94-44$ & Glioblastoma & IV & ++++ \\
$94-517$ & Glioblastoma & IV & +++ \\
$89-34523$ & Glioblastoma & IV & ++ \\
$91-1032$ & Glioblastoma & IV & ++ \\
$94-461$ & Glioblastoma & IV & $(+)$ \\
& & & \\
\hline
\end{tabular}

Immunocytochemistry was performed as described in Methods and rated as - (glioma cells negative), ( + ) (single positive cells, focal pattern), $+($ single positive cells, diffuse pattern), ++ (clusters of positive cells, $<20 \%$ of the glioma cells positive $),+++(20-50 \%$ of the glioma cells positive), and $++++(>50 \%$ of the glioma cells positive).

To assess Fas/APO-1 expression, the glioma cell cultures were covered with trypsin/EDTA for $10 \mathrm{~s}$, incubated for $3 \mathrm{~min}$ at $37^{\circ} \mathrm{C}$, detached mechanically, and washed in cold medium. The cells were resuspended in ice-cold PBS containing 1\% BSA, $10 \mu \mathrm{g} / \mathrm{ml}$ mouse IgG and $0.01 \%$ sodium azide, incubated for $20 \mathrm{~min}$ on ice, centrifuged and labeled with FITC-labeled CD8 ab as a control or with FITC-labeled Fas ab (clone UB2). Endogenous BCL-2 protein levels were assessed by Western blot (6) or by flow cytometry (30). Briefly, $10^{6}$ glioma cells were fixed with 4\% formaldehyde in PBS for $10 \mathrm{~min}$ on ice, permeabilized by the addition of $0.01 \mathrm{~V} \mathrm{5 \%}$ Triton $\mathrm{X}-100$ for $5 \mathrm{~min}$, centrifuged, washed twice with PBS containing $10 \%$ human $A B$ serum and $2 \%$ sheep serum, labeled with $10 \mu \mathrm{g} / \mathrm{ml}$ monoclonal anti-human BCL-2 ab (Dakopatts, Glostrup, Denmark), washed twice with PBS, and stained using sheep anti-mouse IgG-FITC (Sigma Chemical Co.).

Transfections. Human glioma cell lines LN-18, T98G and LN-229 as well as M07e and L-M cells were stably transfected with the BMGNeo expression vector (31) carrying the murine $b c l-2$ gene (32) using a Biorad Gene Pulser $(0.25 \mathrm{~V}, 960 \mu \mathrm{F})$. Transfected cells were cultured in DME/10\% FCS containing G418 $(500 \mu \mathrm{g} / \mathrm{ml})$ for $4-8$ wk before the selection and expansion of single clones. Stable expression of the transfected murine $b c l-2$ gene was confirmed by RNase protection assay (27) and by Western blot. Murine BCL-2 protein was detected using a rabbit ab raised against a synthetic peptide corresponding to amino acids 68-86 of the murine BCL-2 protein (33). Immunostaining was performed with peroxidase-coupled anti-rabbit IgG and enhanced chemiluminescence or with biotinylated anti-rabbit IgG and streptavidin-alkaline phosphatase (Boehringer Mannheim, Rotkreuz, Switzerland).

Detection of BCL-2 protein expression in malignant gliomas in vivo. Immunohistochemical detection of BCL-2 was performed using the microwave oven heating method. Deparaffinized sections were placed in $10 \mathrm{mM}$ citrate buffer ( $\mathrm{pH} 6.0$ ) and incubated in a $750 \mathrm{~W}$ microwave oven for 3 cycles of $5 \mathrm{~min}$ each. The slides were allowed to cool for $20 \mathrm{~min}$, rinsed twice in distilled water, and equilibrated in PBS for 5

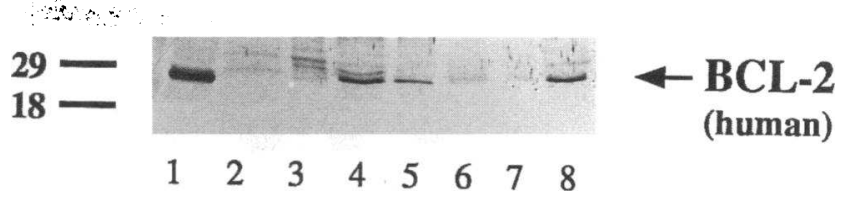

Figure 2. Detection of BCL-2 protein in human malignant gliomas. Soluble protein was harvested from the glioma cells and processed for human BCL-2 Western blot as previously described (6): lane 1, MCF7 mammary carcinoma cells as a positive control; lanes 2-6, human malignant gliomas analysed after enzymatic and mechanical dissociation; lanes 7 and 8 , human malignant gliomas after $24 \mathrm{~h}$ passage in vitro.

min. Sections were then stained with monoclonal ab to human BCL-2 (1:50) and a biotin/avidin-peroxidase-based detection system.

To confirm BCL-2 expression in human malignant gliomas ex vivo by Western blot (6), surgically obtained tumor pieces were dissociated mechanically, digested for $1 \mathrm{~h}$ in collagenase/dispase $(1 \mathrm{mg} / \mathrm{ml})$, filtered through a nylon sieve $(70 \mu \mathrm{m})$, and centrifuged. Erythrocytes were lysed by hypotonic shock treatment and the remaining cells washed in HBSS. Soluble protein was harvested as previously described (6), either immediately after this procedure, or, to eliminate a possible contamination with B or T cells, after a 24 -h passage in vitro and removal of nonadherent cells.

\section{Results}

Human malignant glioma cells express $B C L-2$ protein in vivo. Our previous work had suggested a role for $b c l-2$ in the resistance of Fas/APO-1-positive human glioma cell lines to Fas/ APO-1 ab (6). Therefore we examined the expression of BCL2 protein in human malignant gliomas in vivo by immunocytochemistry (Fig. 1, Table I) and Western blot (Fig. 2). BCL-2 protein was detected in almost all astrocytic brain tumors and was more abundant in anaplastic astrocytomas (WHO grade III) and glioblastomas (WHO grade IV) than in grade I or II astrocytomas (Table I). BCL-2 expression was mainly localized to the nuclear envelope and cytoplasm of glioma cells but also detected in tumor-infiltrating lymphocytes. Proliferating endothelial cells associated with high grade gliomas were negative (Fig. 1). Of 7 grade IV malignant gliomas examined by Western blot (Fig. 2), 3 showed a strong immunoreactive band of 26 $\mathrm{kD}$ (lanes 4, 5, and 8), 3 showed a faint signal (lanes 3, 6, and 7 ) and 1 was negative (lane 2). BCL-2 protein was detected in freshly isolated glioma cells (lanes 4-6) and in dissociated glioma cells incubated for $24 \mathrm{~h}$ and depleted of nonadherent cells (lanes 7 and 8 ). Thus, BCL-2 protein expression of malignant glioma cells is not restricted to long-term cultured glioma cell lines but is also detectable in malignant glioma cells in vivo and appears to increase with malignant progression.

Generation of murine bcl-2 transfectant clones derived from human malignant glioma cell lines. We selected a transfection approach using the murine $b c l-2$ gene for human cell lines to assess expression of endogenous human $b c l-2$ versus transfected murine $b c l-2$. Several independent murine $b c l-2$ clones derived from the glioma cell lines, LN-18, T98G, and LN229, were characterized and compared with pooled neo vector control cells. Antiapoptotic effects of murine $b c l-2$ in human cells have not previously been examined. Since prevention of apoptosis of growth factor-dependent cells after IL-3 deprivation is a classical paradigm of $b c l-2$-mediated rescue from apoptosis (10), we chose as a positive control for the antiapop- 
惫

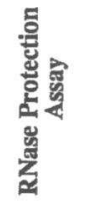

A

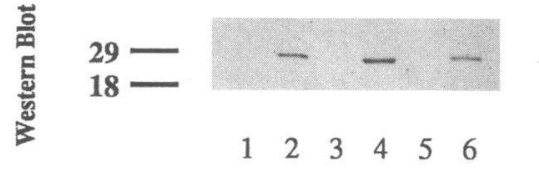

B

$\begin{array}{llllll}1 & 2 & 3 & 4 & 5 & 6\end{array}$

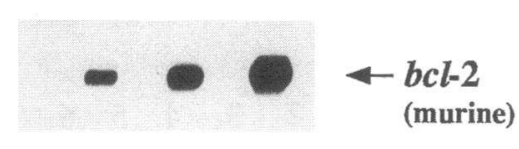

$\leftarrow$ BCL-2

(murine)
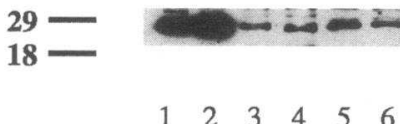

$\leftarrow$ BCL-2

(human)
Figure 3. Expression of transfected and endogenous $b c l-2$ in M07e myeloid leukemia cells and LN-18 and T98G malignant glioma cells. (A) Murine bcl-2 mRNA and protein levels in M07e (lanes 1 and 2), LN-18 (lanes 3 and 4), and T98G (lanes 5 and 6 ) cells transfected with the empty BMGNeo vector (lanes $1,3,5$ ) or the murine $b c l-2$ expression vector (lanes 2, 4, and 6), as assessed by RNase protection assay and Western blot. Equal RNA loading was ascertained by probing for the constitutive transcription factor Sp1. B. Endogenous human BCL-2 protein levels detected by Western blot (for legend, see $A$ ).

totic effects of murine $b c l-2$ in human cells the human IL-3dependent M07e myeloid leukemia cell line which undergoes apoptosis after withdrawal of IL-3. The expression levels of transfected murine $b c l-2$ and endogenous human $b c l-2$ in transfected $b c l-2$ clones were assessed by RNase protection assay and Western blot. Murine $b c l-2$ mRNA and BCL-2 protein were detected in the transfected $b c l-2$ clones but not in neo vector control cells (Fig. $3 \mathrm{~A}$ ). Transfection of murine $b c l-2$ into M07e or glioma cells did not repress endogenous BCL-2 protein (Fig. $3 \mathrm{~B}$ ), consistant with preserved endogenous $\mathrm{bcl}$ 2 mRNA expression in IL-3-dependent murine cells transfected with a retrovirus encoding $b c l-2(10)$. Flow cytometry showed that forced expression of murine $b c l-2$ in the human malignant glioma cell lines LN-18, T98G and LN-229 did not alter their cell surface Fas/APO-1 expression (data not shown).

Bcl-2 inhibits IL-3 deprivation-induced apoptosis of human M07e myeloid leukemia cells. We first established that a murine bcl-2 gene transfer confers protection from apoptosis in human IL-3-dependent M07e cells deprived of IL-3, confirming similar effects of murine $b c l-2$ in murine cells (10). Two M07e $b c l-2$ clones, $b c l-2-A$ and $b c l-2-C$, which expressed high levels of murine BCL-2 protein by Western blot, and M07 vector control cells (neo) showed identical growth patterns in the presence of IL-3 and arrested in $G_{0} / G_{1}$ when deprived of IL-3 for $24 \mathrm{~h}$. M07e clones expressing murine $b c l-2$ showed significantly longer survival after IL-3 deprivation than neo or parent M07e cells (Fig. 4). The extended survival of parent or neo M07e cells corresponded to a strong expression of endogenous BCL2 protein (Fig. $3 \mathrm{~B}$ ). As recently observed in murine IL-3dependent BAF3 cells (34), prolonged IL-3 withdrawal of $b c l$ 2-A and $b c l-2-\mathrm{C}$ clones induced reversible refractoriness to restimulation with IL-3, that is, IL-3 reexposure intervals in excess of $36 \mathrm{~h}$ were required to demonstrate significant $\left[{ }^{3} \mathrm{H}\right]$ -

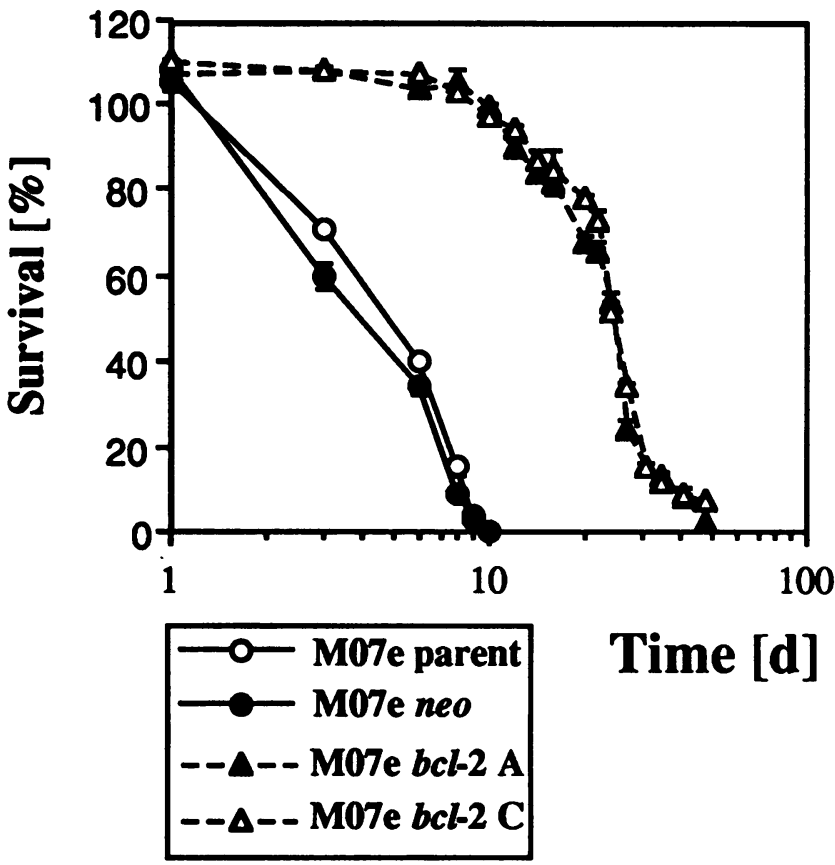

Figure 4. Bcl-2 inhibits apoptosis of IL-3-deprived M07e human leukemia cells. Parent M07e cells $(0)$, M07e neo cells $(\bullet)$ or M07e bcl-2 cells (dotted lines); clone $A,(\Delta)$, and clone $C(\Delta)$ were washed twice in HBSS and resuspended in complete medium lacking IL-3 $\left(2 \times 10^{5}\right.$ cells $/ \mathrm{ml}$ ). Medium was replaced twice a week. Total viable cell yields were determined by trypan blue exclusion at defined time points after IL-3 withdrawal. Data are expressed as mean and SEM of percent viable cells.

thymidine incorporation of M07e cells surviving IL-3 deprivation for $7 \mathrm{~d}$. M07e cells transfected with murine $b c l-2$ were not protected from cytotoxic effects of TNF $\alpha$ or Fas/APO-1 ab in the presence of cycloheximide (CHX) (data not shown).

Bcl-2 abrogates Fas/APO-1 ab-induced apoptosis of human malignant glioma cells. In contrast to M07e myeloid leukemia cells, $b c l-2$ clones derived from all three glioma cell lines acquired resistance to Fas/APO-1-dependent apoptosis (Fig. 5). A comparison of different individual clones derived from each single cell line showed that the degree of protection from Fas/APO$1 \mathrm{ab}$-induced apoptosis depended on the degree of $\mathrm{bcl}-2$ transgene expression (data not shown). Single clones with a high expression level of the transgene were selected for further study ( $\mathrm{LN}$ 18-A4, T98G-A2, LN-229-B2). Protection from Fas/APO-1dependent apoptosis was evident in the presence and absence of actinomycin D (ActD) and CHX. While the antiapoptotic effects of murine $b c l-2$ were most prominent in cell cultures exposed to Fas/APO-1 ab alone or to Fas/APO-1 ab plus ActD, some heterogeneity was noted in glioma cell cultures cotreated with Fas/APO-1 ab and CHX. The CHX-induced augmentation of Fas/APO-1-dependent apoptosis was significantly attenuated in LN-18 cells transfected with murine $b c l-2$ but only moderately in LN-229 cells and insignificantly in T98G cells (Fig. 5, left). Irrespective of whether the cells carried the murine $b c l-2$ transgene or the empty vector (neo), both ActD and CHX enhanced Fas/APO-1 ab-mediated apoptosis of the glioma cells compared with Fas/APO-1 ab treatment alone. ActD and CHX alone were antiproliferative by $\left[{ }^{3} \mathrm{H}\right]$ thymidine incorporation but not cytotoxic by trypan blue exclusion within the time frame of 

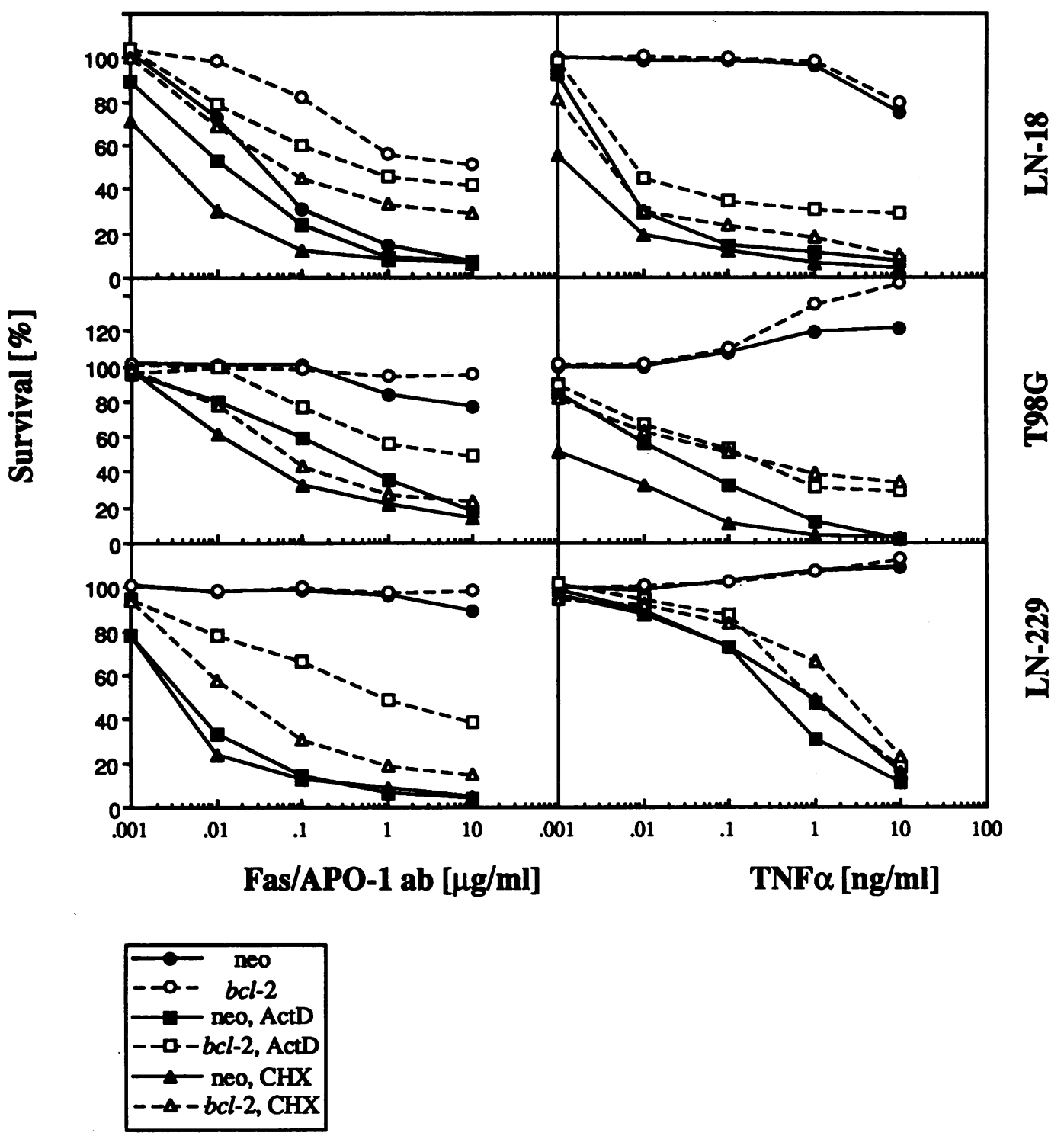

Figure 5. Bcl-2 inhibits apoptosis induced by Fas/APO-1 ab or TNF $\alpha$. LN-18, T98G, or LN-229 clones stably expressing murine bcl-2 (dotted lines, open symbols) or neo vector control cells (straight lines, filled symbols) were exposed to Fas/APO-1 ab (left) or to TNF $\alpha$ (right) in the absence (circles) or presence of ActD $(0.5 \mu \mathrm{g} / \mathrm{ml}$; squares) or CHX $(10 \mu \mathrm{g} / \mathrm{ml}$; triangles) for $16 \mathrm{~h}$. Survival was assessed by crystal violet staining. Data are expressed as mean percent of survival relative to survival of untreated cells or cells exposed to ActD or CHX alone $(n=3)$. SEM were below $5 \%$.

the experiments (data not shown). Consistent with this observation, glioma cells expressing murine $b c l-2$ had no growth or survival advantage over neo cells when exposed to ActD or $\mathrm{CHX}$ for less than $16 \mathrm{~h}$. The cytotoxicity data obtained by crystal violet staining were confirmed by phase contrast microscopy. Compared with neo cells, the $b c l-2$ clones revealed less dissolution of the monolayer and fewer morphological alterations suggestive of apoptosis, including membrane blebbing and nuclear fragmentation (data not shown).

To determine the effects of ActD and $\mathrm{CHX}$ on the expression of the murine $b c l-2$ transgene, RNase protection and Western blot assays were performed on transfected cells that had been treated with inhibitors of RNA and protein synthesis for $16 \mathrm{~h}$ (Fig. 6), corresponding to the time frame of the cytotoxicity experiments (Fig. 5). Although murine $b c l-2$ mRNA levels de- clined within a few hours after ActD exposure, neither ActD nor $\mathrm{CHX}$ induced a prominent loss of transfected murine BCL-2 protein within $16 \mathrm{~h}$ (Fig. 6). Thus, the augmentation of Fas/ APO-1 ab-mediated killing in the presence of ActD or CHX does probably not result from impaired transcription or translation of the $b c l-2$ transgene. These results are consistent with the reported long half-life of the BCL-2 protein of 10-12 $\mathrm{h}$ (35).

Glioma cells expressing murine $b c l-2$ were also more resistant to the cytotoxicity of TNF $\alpha$ in the presence of ActD and CHX (Fig. 5). However, protection from TNF toxicity was moderate compared with protection from Fas/APO-1 ab-induced killing. Previous reports on the role of $b c l-2$ in attenuating TNF toxicity are controversial (36-38), suggesting that other cell type-specific factors modulate the efficacy of $b c l-2$ in this regard. To assess whether the $b c l$-2-mediated mitigation of 


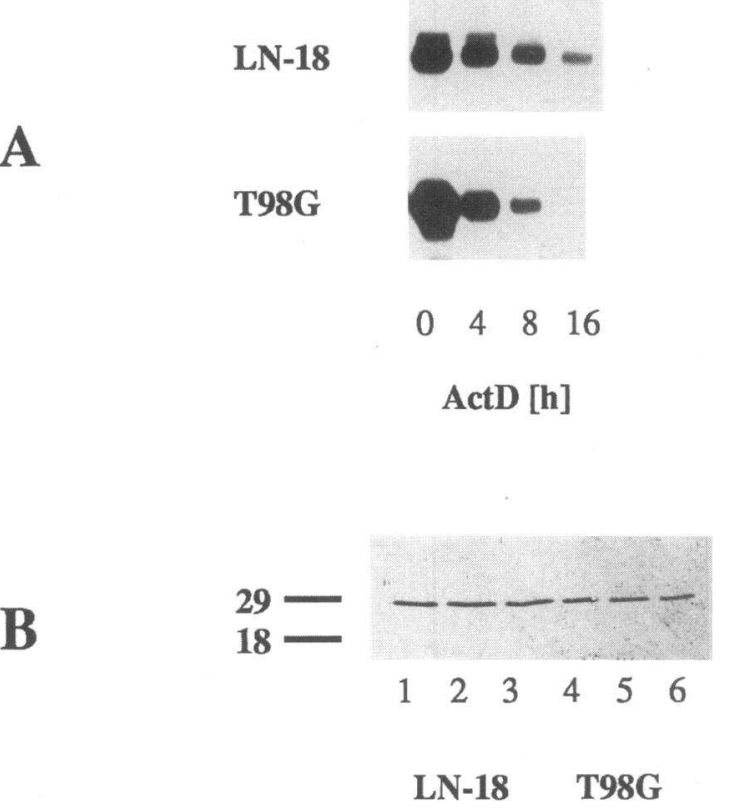

Figure 6. Effects of ActD and CHX on transfected murine bcl-2 transcription and translation in LN-18 and T98G human malignant glioma cells. A. LN-18 and T98G bcl-2 clones were exposed to ActD $(0.5 \mu \mathrm{g} /$ $\mathrm{ml}$ ) for 4,8 , or $16 \mathrm{~h}$. Murine $b c l-2 \mathrm{mRNA}$ expression was assessed by RNase protection assay (27). B. LN-18 or T98G bcl-2 clones were treated with ActD $(0.5 \mu \mathrm{g} / \mathrm{ml})$ or CHX $(10 \mu \mathrm{g} / \mathrm{ml})$ for $16 \mathrm{~h}$. Murine BCL-2 protein was analysed by Western blot as described in Methods (lanes 1, 4, control; lanes 2, 5, ActD; lanes 3, 6, CHX).

TNF $\alpha$ toxicity was a characteristic feature of glioma cells or related more to the use of a strong expression vector, we generated stable $b c l-2$ transfectants of the murine L-M fibroblast cell line, a classical bioassay cell line to measure TNF toxicity (29). Two L-M $b c l-2$ clones with a high expression level of BCL-2 protein by Western blot were partially protected from TNF $\alpha$ toxicity in the presence of ActD, confirming that $b c l-2$ inhibits not only Fas/APO-1-dependent apoptosis but also TNF $\alpha$-induced cytotoxicity. This contrasts with the M07e $b c l-2$ clones $A$ and $C$ which expressed sufficient BCL-2 to survive IL-3 deprivation for 3-4 wk (Fig. 4) but were still as susceptible to TNF $\alpha$ toxicity in the presence of $\mathrm{CHX}$ as parent M07e cells or neo vector control cells. These results indicate that a $b c l-2$ gene transfer does not protect all cell types from TNF $\alpha$-mediated cytotoxicity and may be more effective against Fas/APO-1 abinduced apoptosis than against TNF $\alpha$.

Bcl-2 abrogates Fas/APO-1 ab-induced DNA fragmentation of human malignant glioma cells. In glioma cells induced to undergo Fas/APO-1-dependent apoptosis, DNA breaks are readily detected by in situ DNA end labeling. However, maximal DNA fragmentation does not exceed $20 \%$ of the total genomic DNA, and nucleosomal size DNA laddering assessed by DNA agarose gel electrophoresis is not a prominent feature of Fas/APO-1 ab-induced glioma cell apoptosis (6). To study the effects of forced $b c l-2$ expression on Fas/APO-1 ab-mediated DNA fragmentation, glioma cells were exposed to Fas/APO-1 ab alone, to TNF $\alpha$ alone, or preexposed to TNF $\alpha$ and subsequently treated with Fas/APO-1 ab. Although human glioma cells are resistant to TNF $\alpha$ cytotoxicity in the absence of ActD or $\mathrm{CHX}$, preexposure to TNF $\alpha$ for $24 \mathrm{~h}$ results in a striking

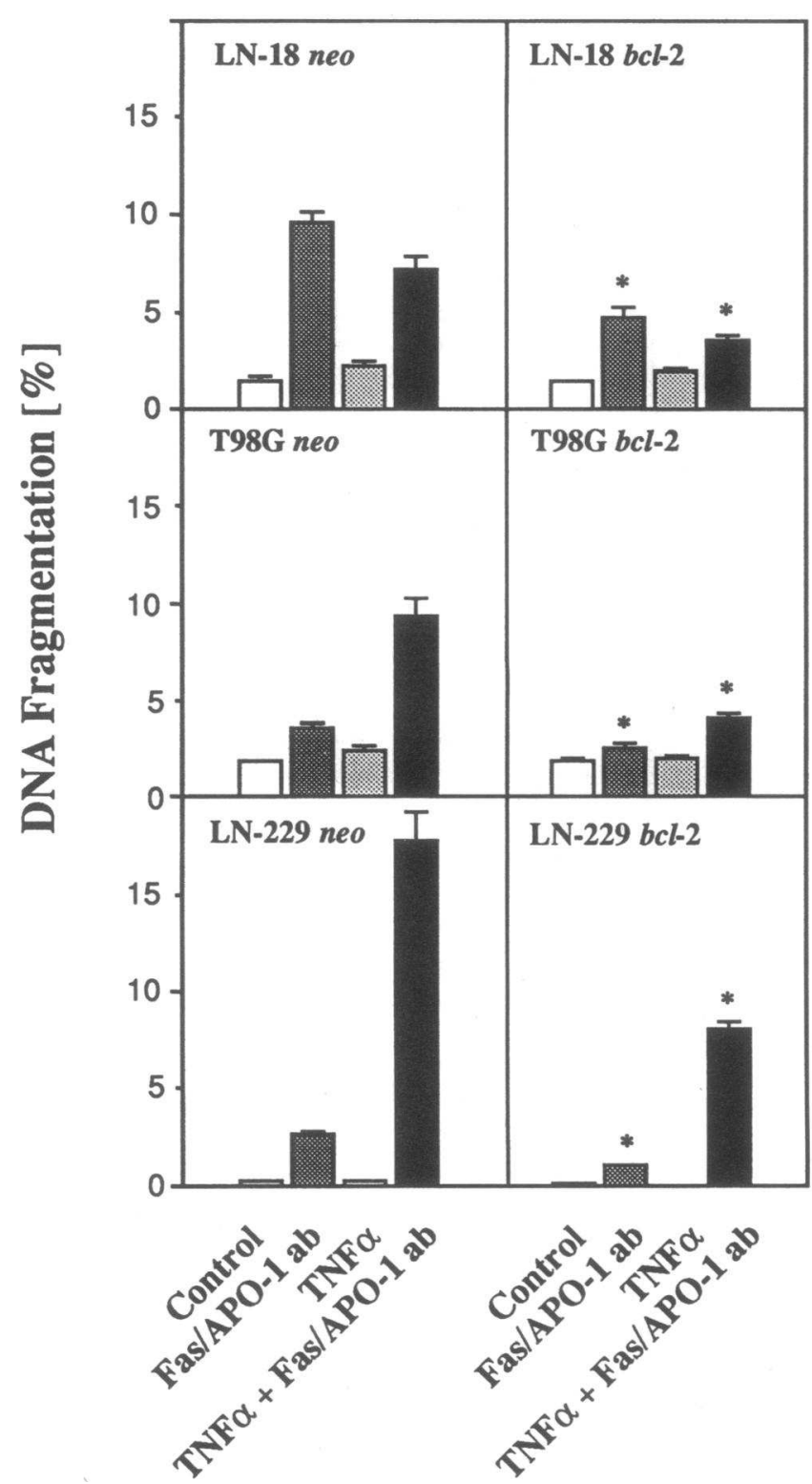

Figure 7. Bcl-2 inhibits Fas/APO-1 ab-mediated DNA fragmentation in human malignant glioma cells. Neo control glioma cells (left) or murine $b c l$-2-transfected clones ( $b c l$-2) (right) were untreated, exposed to Fas/APO-1 ab $(1 \mu \mathrm{g} / \mathrm{ml})$ for $24 \mathrm{~h}$, to TNF $\alpha(10 \mathrm{ng} / \mathrm{ml})$ for $24 \mathrm{~h}$, or consecutively to TNF $\alpha$ and Fas/APO-1 ab. Fragmented and intact DNA from $10^{6}$ glioma cells were measured fluorometrically (6, 27). Data are expressed as mean and SEM of percent DNA fragmentation $\left(n=3,{ }^{*} P<0.03\right.$ by $t$ test for $b c l-2$ cells compared with neo cells).

augmentation of Fas/APO-1 ab-mediated apoptosis (6). Quantitative DNA fluorometry showed that the $b c l$-2-mediated inhibition of Fas/APO-1 ab-induced cytotoxicity was associated with a significant reduction in DNA fragmentation (Fig. 7). In line with the cytotoxicity data shown in Fig. 5, the inhibition of DNA fragmentation was most prominent in bcl-2-transfected LN-18 cells and exceeded 50\%. We observed that DNA fragmentation induced by Fas/APO-1 ab was only partially inhibited by the $b c l-2$ gene transfer even in experiments which showed complete abrogation of Fas/APO-1 ab-induced cell kill- 
ing (data not shown). The partial inhibition of Fas/APO-1 abinduced DNA fragmentation in $b c l-2$ clones versus neo cells is consistent with the notion that $b c l-2$ prevents apoptosis but not initial DNA changes in murine B cells exposed to etoposide (20). Fas/APO-1 ab-induced DNA fragmentation was examined by DNA agarose gel electrophoresis in parallel with the experiments conducted to quantify $b c l-2-$ mediated prevention of DNA fragmentation by DNA fluorometry (Fig. 7). These experiments showed that neither LN-18 nor T98G neo control cells contained significant amounts of fragmented low-molecular weight DNA when DNA was extracted from $10^{7}$ glioma cells exposed sequentially to TNF $\alpha$ and Fas/APO-1 ab (data not shown). However, as previously described (6), DNA laddering became apparent in LN-229 exposed to TNF $\alpha$ and Fas/APO$1 \mathrm{ab}$, consistent with the quantitative DNA fragmentation data (Fig. 7) which yielded the highest percentage of DNA fragmentation under these conditions $(17 \%)$.

The cytotoxicity data presented in Fig. 5 were obtained by crystal violet staining, the conventional assay for TNF $\alpha$ - or Fas/APO-1 ab-mediated killing of adherent cells. This assay considers as dead all floating cells which have detached from the cell culture monolayer. When we assessed DNA fragmentation after Fas/APO-1 ab exposure separately in detached and adherent cells (6), we noted that DNA fragmentation was significantly attenuated in detached $b c l-2$ cells compared with detached neo cells. Although all detached glioma cells had DNA breaks detected by in situ DNA end labeling, the majority excluded trypan blue at $16 \mathrm{~h}$ after Fas/APO-1 ab exposure (data not shown). We then examined whether murine $b c l-2$ expressed in detached glioma cells delayed completion of cell death and whether endogenous $b c l-2$ expression of neo control cells predicted their ability to recover from Fas/APO-1 ab-induced DNA breaks and detachment from the monolayer. Floating cells were collected from the supernatants of glioma cell cultures that had been exposed to Fas/APO-1 ab, washed to remove residual Fas/APO-1 ab, and resuspended in fresh medium. Crystal violet staining performed $14 \mathrm{~d}$ later showed that detachment did not inevitably predict definite cell death because there was significant clonogenicity after Fas/APO-1 ab-induced detachment in bcl-2 compared with neo transfectants (Fig. 8). Further, the survival of neo control cells of the three glioma cell lines correlated with their previously reported endogenous BCL-2 protein levels which are highest in LN-229, moderately high in T98G, and low in LN-18, as assessed by Western blot (6). No colony formation was observed when supernatants containing detached glioma cells were replated without prior centrifugation to remove residual Fas/APO-1 ab (data not shown).

Bcl-2 enhances glioma cell survival after irradiation or exposure to chemotherapy drugs. Bcl-2 has received major attention as a mediator of resistance to irradiation and cancer chemotherapy drugs (9). Since the latter are the two main adjuncts to the neurosurgical treatment of malignant glioma, we compared the survival of $b c l-2$ transfectants and neo control cells of the LN-18 and T98G glioma cell lines after irradiation or exposure to BCNU or cisplatin, two drugs used in the treatment of malignant glioma. Radioresistance was determined as the surviving fraction of glioma cells at $2 \mathrm{~Gy}\left(\mathrm{SF}_{2}\right)$ defined by the extent of proliferation relative to nonirradiated glioma cells 2 wk after irradiation (39). Parent or neo T98G cells were more resistant to irradiation and cisplatin than parent or neo $\mathrm{LN}-18$ cells. Both cell lines were rather resistant to BCNU. Bcl-2 gene transfer enhanced the radioresistance of $\mathrm{LN}-18$ to levels

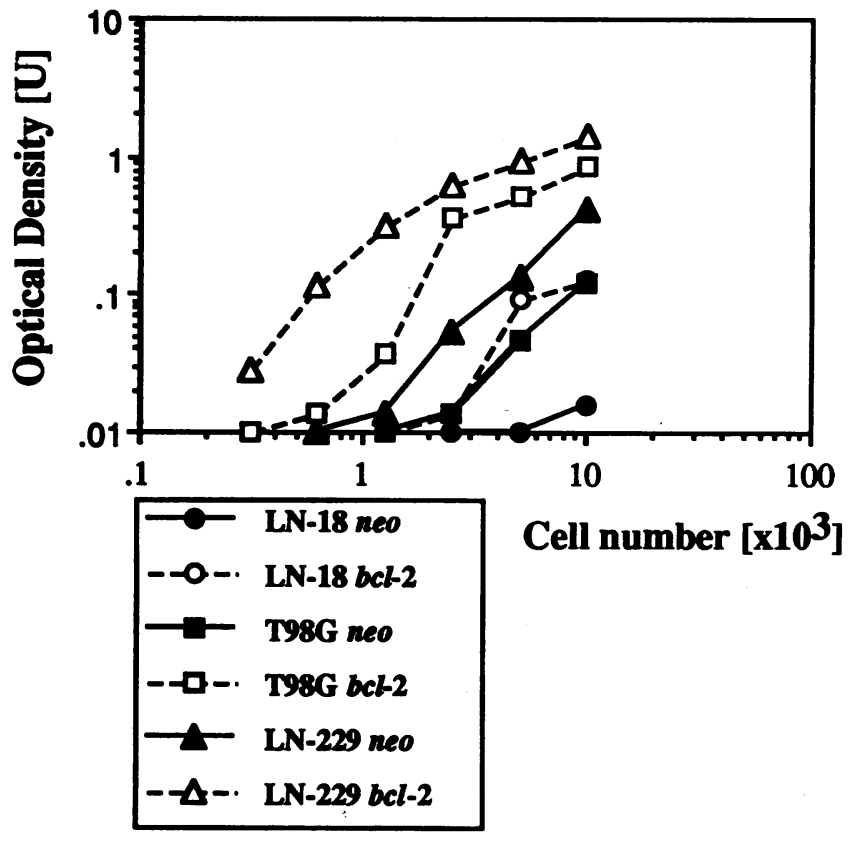

Figure 8. Bcl-2 enhances long-term survival of glioma cells after Fas/ APO-1-induced detachment from the monolayer. Neo control cells (closed symbols, straight lines) or bcl-2 clones (open symbols, dotted lines) of LN-18 (circles), T98G (squares), and LN-229 (triangles) human malignant glioma cells were treated with Fas/APO-1 ab (0.1 $\mu \mathrm{g} / \mathrm{ml}$ for LN-18, $1 \mu \mathrm{g} / \mathrm{ml}$ for T98G and LN-229) for $16 \mathrm{~h}$. T98G and LN-229 cells were pretreated with TNF $\alpha(10 \mathrm{ng} / \mathrm{ml})$ for $24 \mathrm{~h}$. Floating cells were collected from the culture medium, washed in complete medium, and resuspended in fresh medium in 96-well plates at the indicated densities. Survival was assessed $14 \mathrm{~d}$ later by crystal violet staining. Data are expressed as mean optical density units (U). SEM were below $10 \%$. An optical density of $1 \mathrm{U}$ is usually reached at $72 \mathrm{~h}$ after seeding of 10,000 viable glioma cells (data not shown).

comparable to that of parent untransfected T98G cells but did not confer a survival advantage to the constitutively radioresistant T98G cells (Fig. $9 \mathrm{~A}$ ). Bcl-2 shifted the $\mathrm{SF}_{2}$ of $\mathrm{LN}-18$ cells from 0.38 in parent or neo cells to above 0.7 . In contrast, the $\mathrm{SF}_{2}$ even of parent T98G cells exceeded 0.7 and was not significantly enhanced by $b c l-2$. Conversely, $b c l-2$ induced resistance to cisplatin in T98G but not in LN-18 cells (Fig. $9 \mathrm{~B}$ ). $B c l-2$ clones of both cell lines exhibited enhanced survival after exposure to high concentrations of BCNU (Fig. $9 C$ ). Taken together, these data show that $b c l-2$ can protect glioma cells from irradiation and cytotoxic drugs. The extent of protection is determined by the cell line studied and the type of cytotoxic stimulus used.

Cooperative inhibition of Fas/APO-1 ab-mediated apoptosis by bcl-2 and dexamethasone. Preexposure of human malignant glioma cells to dexamethasone attenuates Fas/APO-1 abmediated apoptosis (6). Flow cytometric analysis showed that dexamethasone provided protection of LN-18, T98G and LN229 cells from apoptosis without down-regulating Fas/APO-1 expression and without up-regulating endogenous $b c l-2$ expression (data not shown). Thus, dexamethasone presumably acts on intracellular signalling events triggered by Fas/APO-1 ab. Further, dexamethasone did not modulate transcription from the BMGNeo expression vector (data not shown). As shown in Fig. 10, dexamethasone abrogated Fas/APO-1 ab-mediated gli- 

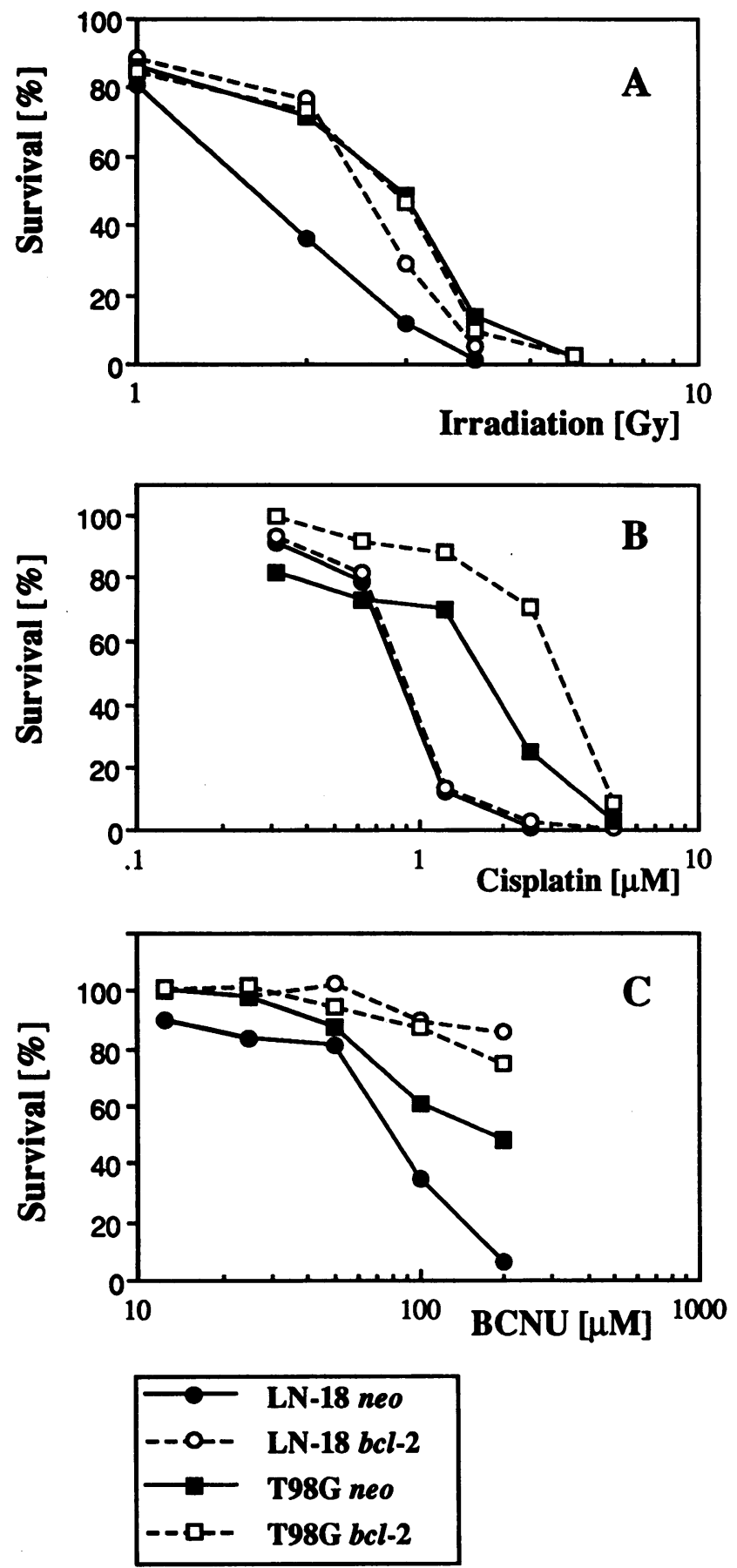

Figure 9. $\mathrm{Bcl}$-2 promotes glioma cell survival after irradiation and inhibits cytotoxicity induced by cisplatin and BCNU. Bcl-2 clones (open symbols, dotted lines) or neo vector control cells (closed symbols, straight lines) of the T98G (squares) and LN-18 (circles) glioma cell lines were irradiated or exposed to cisplatin or BCNU for $24 \mathrm{~h}$ in complete medium. The cell cultures were trypsinized and cultured in 96-well plates $\left(10^{3}\right.$ cells per well) for $14 \mathrm{~d}$ with one medium change at $7 \mathrm{~d}$. Glioma cell proliferation was assessed by crystal violet staining. Data are expressed as mean percent of glioma cell proliferation relative to untreated $b c l-2$ or neo control cultures. SEM were below $10 \%$. The $b c l-2$ gene transfer alone enhanced the clonogenicity of both cell lines as assessed by a standard colony formation assay. In experiments representative of the data shown in Fig. 9, untreated $b c l-2 \mathrm{LN}-18$ and T98G clones showed a 4- and 2-fold increase of OD values compared with neo vector control cells (data not shown). oma cell killing not only of neo control cells but also of the $b c l-2$ clones, suggesting that $b c l-2$ and dexamethasone target distinct steps in the killing cascade of Fas/APO-1-dependent apoptosis and might cooperate in vivo to inhibit immune-mediated glioma cell killing via Fas/APO-1.

Preexposure to cytokines overcomes bcl-2-mediated inhibition of Fas/APO-1-dependent glioma cell apoptosis. Preexposure to TNF $\alpha$, IFN $\gamma$, TGF $\beta_{2}$, IL-1 and IL-8 enhances Fas/ APO-1 ab-mediated glioma cell killing of some glioma cell lines, including T98G and LN-229 (6). In the present study, we have compared the effects of these cytokines on the expression of Fas/APO-1 and bcl-2 with their effects on Fas/APO-1 ab-mediated apoptosis. TNF $\alpha$, IFN $\gamma$ and IL- 1 increased cell surface Fas/APO-1 expression whereas IL- 8 and TGF $\beta$ had no such effect (Table II). In our previous study (6), endogenous bcl-2 expression of the three glioma cell lines, LN-18, T98G, and LN-229, correlated with a requirement for cytokine-mediated presensitization to achieve maximal Fas/APO-1 ab-mediated apoptosis. Here we show that there are no significant differences in endogenous BCL-2 protein levels between untreated glioma cell cultures and cultures exposed to the cytokines ( Table II), suggesting that cytokines induce sensitivity of glioma cells to Fas/APO-1 ab without directly modulating $b c l-2$ expression. Cytokines might therefore also counteract the protection of glioma cells from Fas/APO-1 ab-mediated apoptosis mediated by murine $b c l-2$ gene transfer (Fig. 5). Table III shows that $b c l-2$ clones of the T98G and LN-229 were no longer susceptible to presensitization with IL-1, IL-8 or TGF $\beta$. However, they had not become refractory to IFN $\gamma$ - and TNF $\alpha$ mediated sensitization to Fas/APO-1 ab-mediated killing. Even the T98G and LN-229 bcl-2 clones with the highest levels of $b c l-2$ expression were not completely protected from Fas/APO1 ab-mediated apoptosis when presensitized with IFN $\gamma$ or TNF $\alpha$. The $b c l$-2-mediated attenuation of Fas/APO-1 ab-mediated apoptosis after IFN $\gamma$ or TNF $\alpha$ preexposure (Table III) was moderate compared with the good protection from killing induced by Fas/APO-1 ab alone or in the presence of ActD or CHX (Fig. 5). Flow cytometric analysis of $\mathrm{LN}-229 \mathrm{bcl}-2$ clone B2 confirmed that $b c l-2$ did not inhibit the IFN $\gamma$ - and TNF $\alpha$ mediated up-regulation of cell surface Fas/APO-1 expression (data not shown). Further, the cytokines did not alter transcription from the BMGNeo vector (data not shown). These data suggest that $b c l-2$ does not interfere with cytokine sensitization which targets Fas/APO-1 expression as well as some intermediate steps of the intracellular death cascade.

\section{Discussion}

Fas/APO-1 is a cytokine receptor protein which induces programmed cell death and apoptosis in susceptible target cells. Significant expression of Fas/APO-1 is physiologically restricted to specific tissues including thymus, liver, heart and ovary. In addition to target cell lysis via perforin, Fas/APO-1mediated apoptosis is one of two major effector pathways in $\mathrm{T}$ cell cytotoxicity. Specifically, Fas/APO-1 may play a role in the elimination through apoptosis of syngeneic activated immune effector cells (40-43). The strong expression of Fas/APO1 in many lymphoid malignancies suggests that Fas/APO-1mediated apoptosis may be a promising strategy of immunological tumor therapy (1). Similarly, human malignant glioma cells, unlike untransformed astrocytes (44), express Fas/APO-1 in vitro and in vivo and are susceptible to Fas/APO-1 ab-mediated 


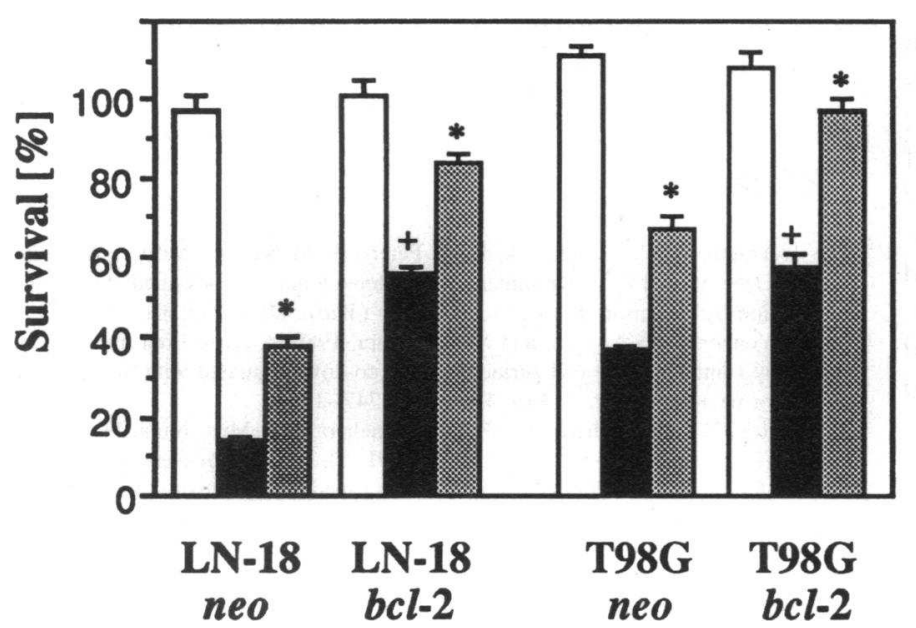

Figure 10. Cooperative inhibition of Fas/APO-1 ab-mediated glioma cell apoptosis by $b c l-2$ and dexamethasone. $B c l-2$ clones or neo vector control cells were pretreated with $10 \mu \mathrm{M}$ dexamethasone or medium alone for $24 \mathrm{~h}$ and subsequently exposed to Fas/APO-1 ab $(0.5 \mu \mathrm{g} / \mathrm{ml})$ for $16 \mathrm{~h}$. T98G was cotreated with $0.5 \mu \mathrm{g} / \mathrm{ml}$ ActD (open bars, dexamethasone alone; filled bars, Fas/APO-1 ab alone; hatched bars, dexamethasone followed by Fas/APO-1 ab). Data are expressed as mean and SEM of percent survival relative to untreated $\mathrm{LN}$ 18 cells or to T98G cells exposed to ActD alone. + indicates significant protection afforded by $b c l-2$ ( $P$ $<0.03$, t-test ). * Indicates significant protection afforded by dexamethasone $(P<0.03$, ANOVA $)$. apoptosis in vitro (6). Expression of the protooncogene $b c l-2$ has emerged as a major mechanism which allows tumor cells to resist physiological apoptosis and apoptosis induced by irradiation and chemotherapy drugs (9).

This study illustrates that malignant gliomas express $b c l-2$ in vivo (Fig. 1) and that forced expression of murine $b c l-2$ in glioma cell lines confers resistance to Fas/APO-1 ab-mediated apoptosis (Fig. 5). Prevention of Fas/APO-1 ab-mediated glioma cell apoptosis by $b c l-2$ operated at a distal step of the apoptotic cascade triggered by Fas/APO-1 ab, since forced $b c l$ 2 expression did not reduce cell surface Fas/APO-1 expression. Further, $b c l-2$ rescued a significant proportion of glioma cells from apoptosis which had suffered Fas/APO-1 ab-induced DNA breaks, including those cells which had detached from

Table II. Effects of Cytokines on Fas/APO-1 and Endogenous BCL-2 Expression of Human Malignant Glioma Cells

\begin{tabular}{|c|c|c|c|c|c|c|c|c|}
\hline & \multicolumn{4}{|c|}{ T98G } & \multicolumn{4}{|c|}{ LN-229 } \\
\hline & \multicolumn{2}{|c|}{ Fas/APO-1 } & \multicolumn{2}{|c|}{ BCL-2 } & \multicolumn{2}{|c|}{ Fas/APO-1 } & \multicolumn{2}{|c|}{ BCL-2 } \\
\hline & MF & SFI & MF & SFI & MF & SFI & MF & SFI \\
\hline Untreated & 287 & 1.65 & 1031 & 3.33 & 212 & 1.51 & 1361 & 3.24 \\
\hline $\mathrm{TNF} \alpha$ & 507 & $2.74 *$ & 856 & 2.08 & 467 & $3.31 *$ & 1337 & 2.41 \\
\hline IFN $\gamma$ & 526 & $2.71 *$ & 1047 & 3.43 & 311 & $2.13^{*}$ & 1174 & 2.51 \\
\hline IL- $1 \beta$ & 430 & $2.34 *$ & 816 & 2.48 & 335 & $2.26^{*}$ & 1254 & 2.69 \\
\hline IL-8 & 286 & 1.64 & 1026 & 3.47 & 202 & 1.45 & 1197 & 2.78 \\
\hline TGF $\beta_{2}$ & 294 & 1.75 & 823 & 2.43 & 197 & 1.40 & 1359 & 3.05 \\
\hline
\end{tabular}

T98G and LN-229 human malignant glioma cells were exposed to medium alone or to TNF $\alpha(10 \mathrm{ng} / \mathrm{ml}), \operatorname{IFN} \gamma(100 \mathrm{U} / \mathrm{ml}), \mathrm{IL}-1 \beta(2.5 \mathrm{ng} /$ $\mathrm{ml})$, IL-8 $(20 \mathrm{ng} / \mathrm{ml})$ or TGF $\beta_{2}(10 \mathrm{ng} / \mathrm{ml})$ for $24 \mathrm{~h}$. Cell surface Fas/ APO-1 expression and BCL-2 levels were assessed by flow cytometry as described in Methods. The table shows representative mean fluorescence $(M F)$ values and the specific fluorescence index $(S F I)$ expressed as the ratio between the MF values obtained with the specific ab and the MF measured with a mouse $\operatorname{IgG}_{1}$ isotype control. TNF $\alpha$, IFN $\gamma$, and IL-1 consistently enhanced Fas/APO-1 expression in both cell lines $(* P$ $<0.03, t$ test). The cytokine-induced changes of BCL-2 expression failed to reach statistical significance $(n=3, t$ test, $P<0.03)$. the cell culture monolayer (Fig. 8). These observations are consistent with the failure of $b c l-2$ to prevent DNA damage induced by some chemotherapy drugs despite its survival-enhancing properties in the same cells $(18,20,21)$. The role of $b c l-2$ in preventing the cytotoxicity of immune effector cells and cytotoxic cytokines like TNF $\alpha$ has remained controversial $(9,36-38,45,46)$. The human glioma cell lines included in this study, which are susceptible to TNF $\alpha$-mediated apoptosis in the presence of ActD or CHX, exhibited enhanced survival after TNF $\alpha$ exposure when transfected with murine bcl-2 (Fig. 5).

A mutual regulation of apoptosis by $b c l-2$ and Fas/APO-1, as directly shown by $b c l-2$ gene transfer in this work, may not be restricted to glioma cells but has previously been suggested,

Table III. Cytokines Overcome bcl-2-mediated Rescue of Human Malignant Glioma Cells from Fas/APO-1 ab-mediated Apoptosis

\begin{tabular}{llllll}
\hline & \multicolumn{2}{c}{ T98G } & & \multicolumn{2}{c}{ LN-229 } \\
\cline { 2 - 3 } \cline { 5 - 6 } & $n e o$ & $b c l-2$ & & $n e o$ & $b c l-2$ \\
\hline Vehicle & $64 \pm 3$ & $91 \pm 3^{*}$ & & $92 \pm 4$ & $99 \pm 5$ \\
TNF $\alpha$ & $29 \pm 1^{\ddagger}$ & $69 \pm 4^{\ddagger *}$ & & $35 \pm 2^{\ddagger}$ & $73 \pm 4^{\ddagger *}$ \\
IFN $\gamma$ & $21 \pm 2^{\ddagger}$ & $41 \pm 2^{\ddagger *}$ & & $32 \pm 5^{\ddagger}$ & $55 \pm 3^{\ddagger *}$ \\
TGF $\beta_{2}$ & $52 \pm 3^{\ddagger}$ & $86 \pm 6^{*}$ & & $72 \pm 5^{\ddagger}$ & $99 \pm 4^{*}$ \\
IL-1 $\beta$ & $46 \pm 3^{\ddagger}$ & $95 \pm 4^{*}$ & & $69 \pm 4^{\ddagger}$ & $90 \pm 4^{*}$ \\
IL-8 & $43 \pm 2^{\ddagger}$ & $83 \pm 3^{*}$ & & $78 \pm 6$ & $99 \pm 5^{*}$ \\
& & & & \\
\hline
\end{tabular}

The glioma cells were incubated in medium alone or pretreated with TNF $\alpha(10 \mathrm{ng} / \mathrm{ml}), \mathrm{IFN} \gamma(100 \mathrm{U} / \mathrm{ml}), \mathrm{IL}-1 \beta(2.5 \mathrm{ng} / \mathrm{ml}), \mathrm{IL}-8(20 \mathrm{ng} /$ $\mathrm{ml})$, or TGF $\beta_{2}(10 \mathrm{ng} / \mathrm{ml})$ for $24 \mathrm{~h}$ in complete medium containing $10 \%$ FCS, washed, and then exposed to Fas/APO-1 ab $(1 \mu \mathrm{g} / \mathrm{ml})$ for $24 \mathrm{~h}$ in medium containing $0.5 \%$ FCS. Percent survival was assessed by crystal violet staining and calculated relative to survival in cultures preexposed to cytokines, and then to vehicle instead of Fas/APO-1 ab. Preexposure to the cytokines alone had no adverse effects on glioma cell viability. Data are expressed as mean and SEM $\left({ }^{\ddagger} P<0.03\right.$, ANOVA, cytokine pretreatment compared with Fas/APO-1 ab treatment alone; ${ }^{*} P$ $<0.03$, ANOVA, cytokine-treated $b c l-2$ clones compared with cytokine-treated neo cells). 
on the basis of correlations between $b c l-2$ and Fas/APO-1 expression, for human peripheral blood cells (47) and lymphoid neoplasms $(48,49)$. Further, coordinate expression of bcl-2 and Fas/APO-1 may limit the cycling of primed T cells which upon progressive differentiation lose $b c l-2$ and gain Fas/APO1 expression (50). Although the antiapoptotic actions of $b c l-2$ have been linked to antioxidant properties (51), this action of $b c l-2$ is unlikely to be responsible for the prevention of Fas/ APO-1-dependent apoptosis since reactive oxygen intermediates have been excluded as mediators of Fas/APO-1 ab-induced cell death $(52,53)$. Recent evidence implicates an acid sphingomyelinase in the TNF receptor- and Fas/APO-1 ab-triggered apoptotic pathway (54). Our study then suggests that the broad spectrum of antiapoptotic actions of $b c l-2$ also encompasses apoptosis mediated through the sphingomyelinase pathway.

BCL-2 protein expression was not restricted to human malignant glioma cell lines but was also detected in human malignant gliomas in vivo. BCL-2 immunoreactivity may correlate with malignant progression since BCL-2-positive tumor cells were more abundant in WHO grade III and IV astrocytomas than in grade I and II astrocytomas (Table I, Fig. 1). The expression of $b c l-2$ in gliomas indicates malignant transformation since untransformed astrocytes do not express BCL-2 protein in vivo $(25,33)$. As previously reported for normal endothelial cells of brain and extracerebral tissues $(24,25)$, endothelial cells in the glial tumors were BCL-2-negative. Cultured endothelial cells express Fas/APO-1 but are resistant to Fas/ APO-1 ab-mediated apoptosis (55). Only endothelial cells of the central nervous system and of the fetal part of the placenta express Fas/APO-1 in vivo (44). The expression of BCL-2 by tumor-infiltrating lymphocytes (Fig. 1) suggests that such immune effector cells could be harvested from gliomas and be expanded in vitro for cellular immunotherapy. However, glioma-derived tumor-infiltrating lymphocytes are rather refractory to activation and expansion in vitro (56). In this regard, it is noteworthy that $\mathrm{T}$ cell apoptosis induced by TGF $\beta_{2}$, which may be responsible for glioma-induced $\mathrm{T}$ cell inactivation (5759 ), proceeds independently of $b c l-2$ expression in vitro (27).

The present study suggests that the antiapoptotic properties of $b c l-2$ may interfere not only with Fas/APO-1 - targeting immunotherapy of human malignant glioma but may also be involved in the resistance of these tumors to cancer chemotherapy and irradiation. The prevention of Fas/APO-1-dependent apoptosis of gliomas cells by dexamethasone was independent of $b c l-2$ expression and of cell surface Fas/APO-1 expression. Since most glioma patients receive steroids for the control of peritumoral edema, these effects of dexamethasone need to be considered in immunotherapy trials targeting Fas/APO-1. The cytoprotective effects of $\mathrm{bcl}-2$ may be overcome by immunostimulatory cytokines like IFN $\gamma$ and TNF $\alpha$. Although the application of IFN $\gamma$ and TNF $\alpha$ alone fails to induce regression of human malignant gliomas $(60,61)$, these cytokines are tolerated by malignant glioma patients at concentrations likely to sensitize human malignant glioma cells to Fas/APO-1 ab-mediated apoptosis in vivo.

\section{Acknowledgments}

The authors thank Ms. T. Michel and Ms. E. Niederer (Zürich, Switzerland) for expert technical assistance, Dr. H. Karasuyama (Basel, Switzerland) and Dr. E. Podack (Miami, FL) for the BMGNeo $b c l-2$ expres- sion vector, and Dr. K. Frei (Zürich, Switzerland) and Dr. S. Krajewski (La Jolla, CA) for helpful discussions.

This study was supported by a grant from the Swiss National Science Foundation (31-28402.90) to A. Fontana. M. Weller is a postdoctoral fellow of the Deutsche Forschungsgemeinschaft. John C. Reed is a Scholar of the Leukemia Society of America.

\section{References}

1. Trauth, B. C., C. Klas, A. M. J. Peters, S. Matzku, P. Möller, W. Falk, K. M. Debatin, and P. H. Krammer. 1989. Monoclonal antibody-mediated tumor regression by induction of apoptosis. Science (Wash. DC). 245:301-305.

2. Yonehara, S., A. Ishii, and M. Yonehara. 1989. A cell-killing monoclonal antibody (anti-Fas) to a cell surface antigen co-downregulated with the receptor of tumor necrosis factor. J. Exp. Med. 169:1747-1756.

3. Itoh, N., S. Yonehara, A. Ishii, M. Yonehara, S. I. Mizushima, M. Sameshima, A. Hase, Y. Seto, and S. Nagata. 1991. The polypeptide encoded by the cDNA for human cell surface antigen Fas can mediate apoptosis. Cell. 66:233243.

4. Oehm, A., I. Behrmann, W. Falk, M. Pawlita, G. Maier, C. Klas, M. LiWever, S. Richards, J. Dhein, B. C. Trauth, H. Ponstingl, and P. H. Krammer. 1992. Purification and molecular cloning of the APO-1 cell surface antigen, a member of the tumor necrosis factor/nerve growth factor receptor superfamily. Sequence identity with the Fas antigen. J. Biol. Chem. 267:10709-10715.

5. Suda, T., T. Takahashi, P. Golstein, and S. Nagata. 1993. Molecular cloning and expression of the Fas ligand, a novel member of the tumor necrosis factor family. Cell. 75:1169-1178.

6. Weller, M., K. Frei, P. Groscurth, P. H. Krammer, Y. Yonekawa, and A. Fontana. 1994. Anti-Fas/APO-1 antibody-mediated apoptosis of cultured human malignant glioma cells. Induction and modulation of sensitivity by cytokines. $J$. Clin. Invest. 94:954-964.

7. Wong, G. H. W., and D. V. Goeddel. 1994. Fas antigen and p55 TNF receptor signal apoptosis through distinct pathways. J. Immunol. 152:1751-1755.

8. Owen-Schaub, L. B., R. Radinsky, E. Kruzel, K. Berry, and S. Yonehara. 1994. Anti-Fas on nonhematopoietic tumors: levels of Fas/APO-1 and bcl-2 are not predictive of biological response. Cancer Res. 54:1580-1586.

9. Reed, J. C. 1994. Bcl-2 and the regulation of programmed cell death. $J$. Cell Biol. 124:1-6.

10. Nuñez, G., L. London, D. Hockenbery, M. Alexander, J. P. McKearn, and S. J. Korsmeyer. 1990. Deregulated bcl-2 gene expression selectively prolongs survival of growth factor-deprived hemopoietic cell lines. J. Immunol. 144:36023610 .

11. Sentman, C. L., J. R. Shutter, D. Hockenbery, O. Kanagawa, and S. J. Korsmeyer. 1991. bcl-2 inhibits multiple forms of apoptosis but not negative selection in thymocytes. Cell. 67:879-888

12. Strasser, A., A. W. Harris, and S. Cory. 1991. bcl-2 transgene inhibits T cell death and perturbs thymic self-censorship. Cell. 67:889-899.

13. Collins, M. K. L., J. Marvel, P. Malde, and A. Lopez-Rivas. 1992. Interleukin 3 protects murine bone marrow cells from apoptosis induced by DNA damaging agents. J. Exp. Med. 176:1043-1051.

14. Epperly, M. W., M. A. Santucci, J. C. Reed, D. Shields, A. Halloran, and J. S. Greenberger. 1994. Expression of the human Bcl-2 transgene increases the radiation resistance of a hematopoietic progenitor cell line. Rad. Oncol. Invest. 2:77-83.

15. Griffiths, S. D., D. T. Goodhead, S. J. Marsden, E. G. Wright, S. Krajewski, J. C. Reed, S. J. Korsmeyer, and M. Greaves. 1994. Interleukin 7-dependent B lymphocyte precursor cells are ultrasensitive to apoptosis. J. Exp. Med. 179:17891797.

16. Miyashita, T., and J. C. Reed. 1992. Bcl-2 gene transfer increases relative resistance of S49.1 and WEHI7.2 lymphoid cells to cell death and DNA fragmentation induced by glucocorticoids and multiple chemotherapeutic drugs. Cancer Res. 52:5407-5411

17. Miyashita, T., and J. C. Reed. 1993. Bcl-2 oncoprotein blocks chemotherapy-induced apoptosis in a human leukemia cell line. Blood. 81:151-157.

18. Fisher, T. C., A. E. Milner, C. D. Gregory, A. L. Jackman, G. W. Aherne, J. A. Hartley, C. Dive, and J. A. Hickman. 1993. Bcl-2 modulation of apoptosis induced by anticancer drugs: resistance to thymidilate stress is independent of classical resistance pathways. Cancer Res. 53:3321-3326.

19. Hanada, M., S. Krajewski, S. Tanaka, D. Cazals-Hatem, B. A. Spengler, R. A. Ross, J. L. Biedler, and J. C. Reed. 1993. Regulation of Bcl-2 oncoprotein levels with differentiation of human neuroblastoma cells. Cancer Res. 53:49784986.

20. Kamesaki, S., H. Kamesaki, T. J. Jorgensen, A. Tanizawa, Y. Pommier, and J. Cossman. 1993. bcl-2 protein inhibits etoposide-induced apoptosis through its effects on events subsequent to topoisomerase II-induced DNA strand breaks and their repair. Cancer Res. 53:4251-4256.

21. Walton, M. I., D. Whysong, P. M. O'Connor, D. Hockenbery, S. J. Korsmeyer, and K. W. Kohn. 1993. Constitutive expression of human $b c l-2$ modulates 
nitrogen mustard and camptothecin induced apoptosis. Cancer Res. 53:18531851

22. McDonnell, T. J., P. Troncoso, S. M. Brisbay, C. Logothetis, L. W. K Chung, J.-T. Hsieh, S.-M. Tu, and M. L. Campbell. 1992. Expression of the protooncogene $b c l-2$ in the prostate and its association with emergence of androgen-independent prostate cancer. Cancer Res. 52:6940-6944.

23. Castle, V. P., K. P. Heidelberger, J. Bromberg, X. Ou, M. Dole, and G. Nuñez. 1993. Expression of the apoptosis-suppressing protein $b c l-2$, in neuroblastoma is associated with unfavorable histology and N-myc amplification. Am. J. Pathol. 143:1543-1550.

24. Hockenbery, D. M., M. Zutter, W. Hickey, M. Nahm, and S. J. Korsmeyer. 1991. BCL2 protein is topographically restricted in tissues characterized by apoptotic cell death. Proc. Natl. Acad. Sci. USA. 88:6961-6965.

25. Merry, D. E., D. J. Veis, W. F. Hickey, and S. J. Korsmeyer. 1994. bcl2 protein expression is widespread in the developing nervous system and retained in the adult PNS. Development. 120:301-311.

26. Reed, J. C., L. Meister, S. Tanaka, M. Cuddy, S. Yum, C. Geyer, and D. Pleasure. 1991. Differential expression of $b c l 2$ protooncogene in neuroblastoma and other human tumor cell lines of neural origin. Cancer Res. 51:6529-6538.

27. Weller, M., D. B. Constam, U. Malipiero, and A. Fontana. 1994. Transforming growth factor- $\beta_{2}$ induces apoptosis of murine $T$ cell clones without downregulating $b c l-2$ mRNA expression. Eur. J. Immunol. 24:1293-1300.

28. Frei, K., D. Piani, U. V. Malipiero, E. Van Meir, N. de Tribolet, and A. Fontana. 1992. Granulocyte-macrophage colony-stimulating factor (GM-CSF) production by glioblastoma cells. Despite the presence of inducing signals GMCSF is not expressed in vivo. J. Immunol. 148:3140-3146.

29. Frei, K., C. Siepl, P. Groscurth, S. Bodmer, C. Schwerdel, and A. Fontana. 1987. Antigen presentation and tumor cytotoxicity by interferon- $\gamma$-treated microglial cells. Eur. J. Immunol. 17:1271-1278.

30. Aiello, A., D. Delia, M. G. Borrello, D. Biassoni, R. Giardini, E. Fontanella, F. Pezzella, K. Pulford, M. Pierotti, and G. Della Porta. 1992. Flow cytometric detection of the mitochondrial BCL-2 protein in normal and neoplastic human lymphoid cells. Cytometry. 13:502-509.

31. Karasuyama, H., and F. Melchers. 1988. Establishment of mouse cell lines which constitutively secrete large quantities of interleukin $2,3,4$ or 5 , using modified cDNA expression vectors. Eur. J. Immunol. 18:97-104.

32. Deng, G., and E. R. Podack. 1993. Suppression of apoptosis in a cytotoxic T-cell line by interleukin 2-mediated gene transcription and deregulated expression of the protooncogene bcl-2. Proc. Natl. Acad. Sci. USA. 90:2189-2193.

33. Miyashita, T., S. Krajewski, M. Krajewska, H. G. Wang, H. K. Lin, D. A. Lieberman, B. Hoffman, and J. C. Reed. 1994. Tumor suppressor p53 is a regulator of bcl-2 and bax gene expression in vitro and in vivo. Oncogene. 9:1799-1805.

34. Marvel, J., G. R. Perkins, A. Lopez Rivas, and M. K. L. Collins. 1994. Growth factor starvation of bcl-2 overexpressing murine bone marrow cells induced refractoriness to IL-3 stimulation of proliferation. Oncogene. 9:1117-1122.

35. Kitada, S., S. Takayama, K. DeRiel, S. Tanaka, and J. C. Reed. 1994. Reversal of chemoresistance of lymphoma cells by antisense-mediated reduction of bcl-2 gene expression. Antisense Res. Dev. 4:71-79.

36. Hennet, T., G. Bertoni, C. Richter, and E. Peterhans. 1993. Expression of BCL-2 protein enhances the survival of mouse fibrosarcoid cells in tumor necrosis factor-mediated cytotoxicity. Cancer Res. 53:1456-1460.

37. Itoh, N., Y. Tsujimoto, and S. Nagata. 1993. Effect of bcl-2 on Fas antigenmediated cell death. J. Immunol. 151:621-627.

38. Vanhaesebroeck, B., J. C. Reed, D. De Valck, J. Grooten, T. Miyashita, S. Tanaka, R. Beyaert, F. Van Roy, and W. Fiers. 1993. Effect of $b c l-2$ protooncogene expression on cellular sensitivity to tumor necrosis factor-mediated cytotoxicity. Oncogene. 8:1075-1081.

39. Taghian, A., J. Ramsay, J. Allalunis-Turner, W. Budach, D. Gioioso, F. Pardo, P. Okunieff, N. Bleehen, R. Urtasun, and H. Suit. 1993. Intrinsic radiation sensitivity may not be the major determinant of the poor clinical outcome of glioblastoma multiforme. Int. J. Radiation Oncology Biol. Phys. 25:243-249.

40. Owen-Schaub, L. B., S. Yonehara, W. L. Crump III, and E. A. Grimm. 1992. DNA fragmentation and cell death is selectively triggered in activated human lymphocytes by Fas antigen engagement. Cell. Immunol. 140:197-205.

41. Rouvier, E., M. L. Luciani, and P. Golstein. 1993. Fas involvement in Ca2+-independent T cell-mediated cytotoxicity. J. Exp. Med. 177:195-200.

42. Vignaux, F., and P. Golstein, 1994. Fas-based lymphocyte-mediated cyto- toxicity against syngeneic activated lymphocytes: a regulatory pathway? Eur. J. Immunol. 24:923-927.

43. Kägi, D., F. Vignaux, B. Ledermann, K. Bürki, V. Depraetere, S. Nagata, H. Hengartner, and P. Golstein. 1994. Fas and perforin pathways as major mechanisms of T cell-mediated cytotoxicity. Science (Wash. DC). 265:528-530.

44. Leithäuser, F., J. Dhein, G. Mechtersheimer, K. Koretz, S. Brüderlein, C Henne, A. Schmidt, K. M. Debatin, P. H. Krammer, and P. Möller. 1993. Constitutive and induced expression of APO-1, a new member of the nerve growth factor/ tumor necrosis factor receptor superfamily, in normal and neoplastic cells. Lab. Invest. 69:415-429.

45. Vaux, D. L., H. L. Aguila, and I. L. Weissman. 1992. Bcl-2 prevents death of factor-deprived cells but fails to prevent apoptosis in targets of cell mediated killing. Int. Immunol. 4:821-824.

46. Torigoe, T., J. A. Millan, S. Takayama, R. Taichman, T. Miyashita, and J. C. Reed. 1994. Bcl-2 inhibits T-cell-mediated cytolysis of a leukemia cell line. Cancer Res. 54:4851-4854.

47. Iwai, K., T. Miyawaki, T. Takizawa, A. Konno, K. Ohta, A. Yachie, H. Seki, and N. Taniguchi. 1994. Differential expression of bcl-2 and susceptibility to anti-Fas-mediated cell death in peripheral blood lymphocytes, monocytes, and neutrophils. Blood. 84:1201-1208.

48. Mapara, M. Y., R. Bargou, C. Zugck, H. Döhner, F. Ustaoglu, R. R. Jonker, P. H. Krammer, and B. Dörken. 1993. APO-1 mediated apoptosis or proliferation in human chronic B lymphocytic leukemia: correlation with bcl-2 oncogene expression. Eur. J. Immunol. 23:702-708.

49. Kondo, E., T. Yoshino, I. Yamadori, Y. Matsuo, N. Kawasaki, J. Minowada, and T. Akagi. 1994. Expression of Bcl-2 protein and Fas antigen in nonHodgkin's lymphomas. Am. J. Pathol. 145:330-337.

50. Salmon, M., D. Pilling, N. J. Borthwick, N. Viner, G. Janossy, P. A. Bacon, and A. N. Akbar. 1994. The progressive differentiation of primed T cells is associated with an increasing susceptibility to apoptosis. Eur. J. Immunol. 24:892-899.

51. Hockenbery, D. M., Z. N. Oltvai, X. M. Yin, C. L. Milliman, and S. J. Korsmeyer. 1993. Bcl-2 functions in an antioxidant pathway to prevent apoptosis. Cell. 75:241-251.

52. Hug, H., M. Enari, and S. Nagata. 1994. No requirement of reactive oxygen intermediates in Fas-mediated apoptosis. FEBS (Fed. Eur. Biochem. Soc.) Lett. 351:311-313.

53. Schulze-Osthoff, K., P. H. Krammer, and W. Dröge. 1994. Divergent signalling via APO-1/Fas and the TNF receptor, two homologous molecules involved in physiological cell death. EMBO (Eur. Mol. Biol. Organ.) J. 13:45874596.

54. Cifone, M. G., R. De Maria, P. Roncaioli, M. R. Rippo, M. Azuma, L. L. Lanier, A. Santoni, and R. Testi. 1994. Apoptotic signaling through CD95 (Fas/ Apo-1) activates an acidic sphingomyelinase. J. Exp. Med. 177:1547-1552.

55. Richardson, B. C., N. D. Lalwani, K. J. Johnson, and R. M. Marks. 1994 Fas ligation triggers apoptosis in macrophages but not endothelial cells. Eur. J. Immunol. 24:2640-2645.

56. Miescher, S., T. L. Whiteside, N. De Tribolet, and V. Von Fliedner. 1988 In situ characterization, clonogenic potential, and antitumor cytolytic activity of $\mathrm{T}$ lymphocytes infiltrating human brain cancers. J. Neurosurg. 68:438-448.

57. Fontana, A., H. Hengartner, N. de Tribolet, and E. Weber. 1984. Glioblastoma cells release interleukin 1 and factors inhibiting interleukin 2-mediated effects. J. Immunol. 132:1837-1844.

58. Wrann, M., S. Bodmer, R. De Martin, C. Siepl, R. Hofer-Warbinek, K. Frei, E. Hofer, and A. Fontana. 1987. T cell suppressor factor from human glioblastoma cells is a 12.5 -kd protein closely related to transforming growth factor- $\beta$. EMBO (Eur. Mol. Biol. Organ.) J. 6:1633-1636.

59. De Martin, R., B. Haendler, R. Hofer-Warbinek, H. Gaugitsch, M. Wrann, H. Schlüsener, J. M. Seifert, S. Bodmer, A. Fontana, and E. Hofer. 1987. Complementary DNA for human glioblastoma-derived T cell suppressor factor, a novel member of the transforming growth factor- $\beta$ gene family. EMBO (Eur. Mol. Biol. Organ.) J. 6:3673-3677

60. Yoshida, J., T. Wakabayashi, M. Mizuno, K. Sugita, T. Yoshida, S. Hori, T. Mori, T. Sato, A. Karashima, K. Kurisu, K. Kiya, and T. Uozumi. 1992 Clinical effect of intra-arterial tumor necrosis factor- $\alpha$ for malignant glioma. $J$. Neurosurg. 77:78-83.

61. Färkkila, M., J. Jääskeläinen, M. Kallio, G. Blomstedt, R. Raininko, P. Virkkunen, A. Paetau, H. Sarelin, and M. Mäntyla. 1994. Randomised, controlled study of intratumoral recombinant $\gamma$-interferon treatment in newly diagnosed glioblastoma. Br. J. Cancer. 70:138-141. 